"Government expenditure and macroeconomic stability conundrum in Zimbabwe"

\begin{tabular}{|c|c|c|}
\hline AUTHORS & \multicolumn{2}{|l|}{ Brian Tavonga Mazorodze } \\
\hline ARTICLE INFO & \multicolumn{2}{|c|}{$\begin{array}{l}\text { Harris Maduku and Brian Tavonga Mazorodze (2021). Government expenditure } \\
\text { and macroeconomic stability conundrum in Zimbabwe. Economics of } \\
\text { Development, 20(2), 10-26. doi:10.21511/ed.20(2).2021.02 }\end{array}$} \\
\hline DOI & \multicolumn{2}{|c|}{ http://dx.doi.org/10.21511/ed.20(2).2021.02 } \\
\hline RELEASED ON & \multicolumn{2}{|l|}{ Wednesday, 29 December 2021} \\
\hline RECEIVED ON & \multicolumn{2}{|l|}{ Friday, 18 June 2021} \\
\hline ACCEPTED ON & \multicolumn{2}{|l|}{ Sunday, 20 June 2021} \\
\hline LICENSE & \multicolumn{2}{|c|}{$\begin{array}{l}\text { This work is licensed under a Creative Commons Attribution } 4.0 \text { International } \\
\text { License }\end{array}$} \\
\hline JOURNAL & \multicolumn{2}{|l|}{ "Economics of Development" } \\
\hline ISSN PRINT & \multicolumn{2}{|l|}{$1683-1942$} \\
\hline ISSN ONLINE & \multicolumn{2}{|l|}{$2304-6155$} \\
\hline PUBLISHER & \multicolumn{2}{|c|}{ LLC "Consulting Publishing Company "Business Perspectives" } \\
\hline FOUNDER & \multicolumn{2}{|c|}{ Simon Kuznets Kharkiv National University of Economics } \\
\hline$\sigma^{\circ}$ & 4 & 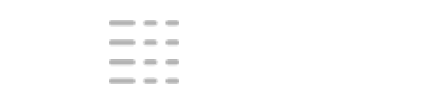 \\
\hline NUMBER OF REFERENCES & NUMBER OF FIGURES & NUMBER OF TABLES \\
\hline 30 & 5 & 9 \\
\hline
\end{tabular}

(c) The author(s) 2021. This publication is an open access article. 


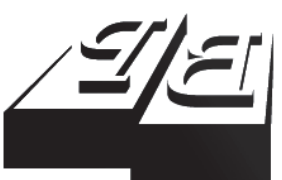

BUSINESS PERSPECTIVES

Publisher

LLC "CPC "Business Perspectives"

Hryhorii Skovoroda lane, 10,

Sumy, 40022, Ukraine

www.businessperspectives.org

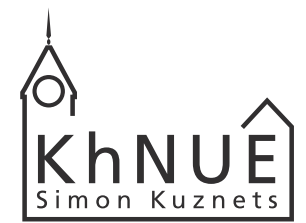

S. KUZNETS KHNUE

Founder

Simon Kuznets Kharkiv National University of Economics, Nauky avenue, 9-A, Kharkiv, 61166,

Ukraine

http://www.hneu.edu.ua/

Received on: 18th of June, 2021 Accepted on: 20th of June, 2021 Published on: 29th of December, 2021

(c) Harris Maduku,

Brian Tavonga Mazorodze, 2021

Harris Maduku, post-doc, Tshwane University of Technology,

South Africa.

Brian Tavonga Mazorodze, postdoc, University of Zululand, South Africa.

\section{GOVERNMENT EXPENDITURE AND MACROECONOMIC STABILITY CONUNDRUM IN ZIMBABWE}

\begin{abstract}
The objective of this paper was to explore the effect of government expenditure growth on macroeconomic stability in Zimbabwe. Public expenditure has grown over time but as per a priori expectations, other macroeconomic variables have not been forth coming. What the country has actually experienced is prolonged macroeconomic instability. The paper contributes to the body of literature in two ways, (1) by creating a macroeconomic instability index and (2) by being the first in the Zimbabwean context to explore this conundrum. To achieve the main objective of the paper, the study used a cointegrated vector error correction model (VECM) and Granger causality with data spanning 1981 to 2019. The study did not find a statistically significant relationship between government expenditure and macroeconomic stability as argued mostly by the Keynesians. However, according to a priori expectations, the relationship turned out to be rightly negative. To buttress the Cointegrated-VECM results, granger causality tests were also conducted where no causality was found from government spending to macroeconomic stability, and vice versa (causality running from instability to government spending). This paper recommends that, Zimbabwe's policy makers may need to consider proactive government spending or policies, since that helps the economy to successfully avoid possible risks such as macroeconomic instability. When policies are proactive rather than reactive, that helps by seizing untapped opportunities, and the economy justly avoids consequences of reactive governance.
\end{abstract}

\section{Keywords}

JEL Classification macroeconomic stability, government expenditure, government debt, economic growth, unemployment, poverty

E62, H00, H20, H50, H68, O01
Харріс Мадуку (Південна Африка),

Браян Тавонга Мазородзе (Південна Африка)

\section{ДЕРЖАВНІ ВИТРАТИ ТА ЗАГАДКА МАКРОЕКОНОМІЧНОЇ СТАБІЛЬНОСТІ У ЗІМБАБВЕ}

\section{Анотація}

Метою цієї статті було дослідження впливу зростання державних витрат на макроекономічну стабільність у Зімбабве. Державні витрати з часом зростали, але, згідно 3 апріорними очікуваннями, інші макроекономічні змінні не з'являлися. Насправді, країна пережила тривалу макроекономічну нестабільність. Документ робить внесок у сукупність літератури за двома напрямками: (1) шляхом створення індексу макроекономічної нестабільності та (2) $€$ першим у контексті Зімбабве, хто дослідив цю загадку. Для досягнення головної мети, у дослідженні використовувалася коінтегрована векторна модель корекції помилок (VECM) i причинно-наслідковий зв'язок Грейнджера з даними за період з 1981 по 2019 рік. Дослідження не виявило статистично значущого зв'язку між державними витратами та макроекономічною стабільністю, як стверджували переважно кейнсіанці. Однак, за апріорними очікуваннями, взаємозв’язки виявилися справедливо негативними. Щоб підтвердити результати CointegratedVECM, також були проведені тести на причинно-наслідковий зв'язок Грейнджера, де не було виявлено причинно-наслідкового зв'язку між державними витратами і макроекономічною стабільністю, і навпаки (причинно-наслідковий зв'язок від нестабільності до державних витрат). У цьому документі рекомендується, щоб директивні органи Зімбабве розглянули можливість проведення активної державної політики чи витрат, оскільки це допомагає економіці успішно уникати можливих ризиків, таких як макроекономічна нестабільність. Коли політика має скоріше випереджальний, ніж реактивний характер, це допоможе скористатися невикористаними можливостями, і економіка справедливо уникатиме наслідків реактивного управління.
Ключові слова

Класифікація JEL макроекономічна стабільність, державні витрати, державний борг, економічне зростання, безробіття, бідність

E62, H00, H20, H50, H68, O01 


\section{INTRODUCTION}

Zimbabwe has battled the twin problem of fiscal and current account deficit since the late 1990s. The country has run an unsustainable public debt for more than a decade, and that has threatened its macroeconomic stability. The government lack budgetary discipline and also huge appetite to spend whilst lacking capacity to enlarge its national purse. The term "Macroeconomic stability" is defined as an economic environment of a country that is less vulnerable to external shocks leading to a very sustainable economic growth trajectory (Gupta et al., 2005). The objective of this paper was to understand the relationship between government expenditure and macroeconomic stability in Zimbabwe. The motivation was government spending, which has grown over the years (see Figure 1), while the response of other key economic variables, such as exports and economic growth, was not expected (Zimstat, 2018).

Conventional knowledge according to Keynesian theory argues that government expenditure is a necessary tool for stimulating a struggling economy. However, as for Zimbabwe, government expenditure has been increasing overtime, but the country has not achieved economic prosperity. This paper becomes the first in Zimbabwe to the best of the researchers' knowledge to investigate this relationship using a macroeconomic instability index created from principal component analysis. That gives confidence that the gaps covered by this paper relate to both the measure of macroeconomic stability (methodological) and also being the first paper in the Zimbabwean context, revealing the relationship.

\section{BACKGROUND OF THE STUDY}

Theoretically, classical economists, the Keynesians and the Wagner's law does not all agree on the involvement of government in the economy. However, Keynes believed that increasing government spending could help stimulate the economy during a recession. Available studies on the expenditure and economic growth relationship give inconclusive findings. Both positive and negative association was found in the literature. This study seeks to answer how Zimbabwe's government expenditure impacted macroeconomic instability over the years. The paper will answer this question by examining the relationship between government spending and the macroeconomic instability index (proxy for macroeconomic stability) in Zimbabwe from 1981 to 2019.

The Zimbabwean economy contracted from 1998 to 2008, this period has numerous popular situations for Zimbabwe, including the civil war participation in the Democratic Republic of Congo (DRC), the compensation of the war veterans from an unbudgeted purse, the violent disposition of white farmers and the hyper-inflation that reached more than $300 \mathrm{mln}$ percent by the fourth quarter of 2008 . However, following the power sharing agreement between the biggest three political parties in the country in 2009, the economy recorded an average growth of more than $10 \%$ per year for the period 2010-2013, before it started stalling again to figures below 3\% in the period 2014-2017 (Zimstat, 2018).

One of the biggest current spending zones for the government is its huge wage bill which is estimated to average between $70-80 \%$ of government spending denying the government space for capital expenditures or public investments that can create jobs and demand in the economy like energy, road and dam construction (Zimbabwe Ministry of Finance, 2018). The relationship of government expenditure and revenue has refused to consolidate and it has remained unbalanced overtime since spending keep increasing while revenues keep following a sluggish trend leading to cumulative government debts. The persistence in this public or government debt has been described by many as the elephant in the room (Daily news, 2018). This ever increasing government debt has been threatening macroeconomic stability in the country hence motivating researchers to investigate the link. Figure 1 shows the relationship between income and expenditure in Zimbabwe.

Figure 1 displays the trend of government expenditure overtime against its revenues that are not stable overtime. It would be expected that economic growth influence growth of government revenue or the other way round but the Zimbabwean situation has only been a quagmire. In the midst of increasing government spending and macroeconomic instability, the government has tight a fiscal space to maneuver and to channel spending in needy areas 


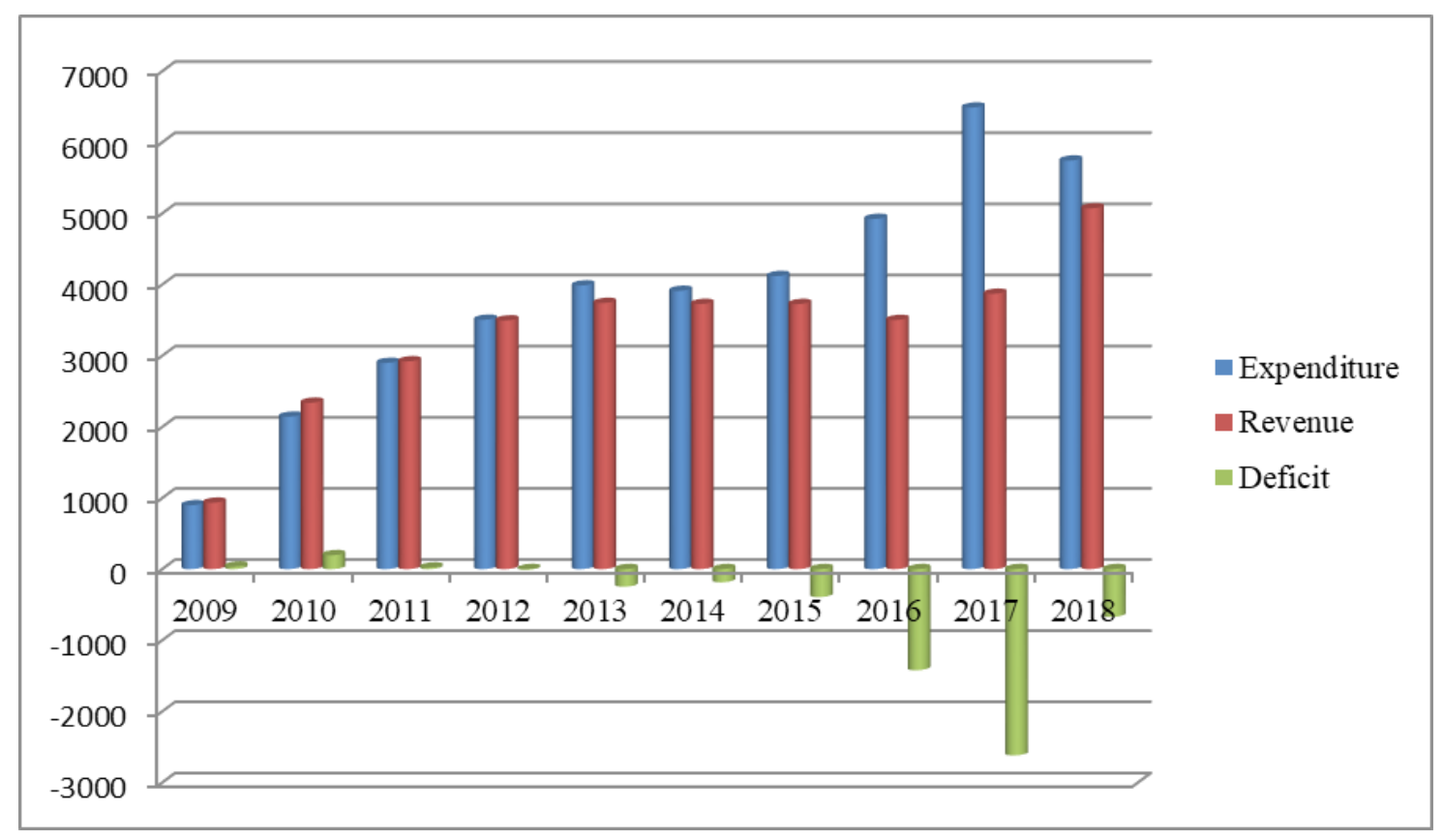

Source: Zimbabwe Ministry of Finance (2018).

Figure 1. Expenditure vs Revenue in bln

like infrastructure and social services delivery. Public spending is estimated to have increased by $25 \%$ compared to 2016 levels whilst gross domestic product (GDP) only increased by 7\% and this spending is hugely recurrent expenditure. If combined, it adds to $90 \%$ of government spending with only $10 \%$ remaining to cover the rest. The ratio of government spending to GDP has averaged between 26 to 30\% from the period 2010 to 2017.

When compared to other SADC countries, the Zimbabwean situation does not look alien, although public recurrent spending is too stalling the economy. The economy has been failing to sustain the size of the country's public sector. This paper argues that, the size of the public sector is too big for the economy and that puts the country far from deliverables such as quality public service and ability to conduct a sound fiscal policy.

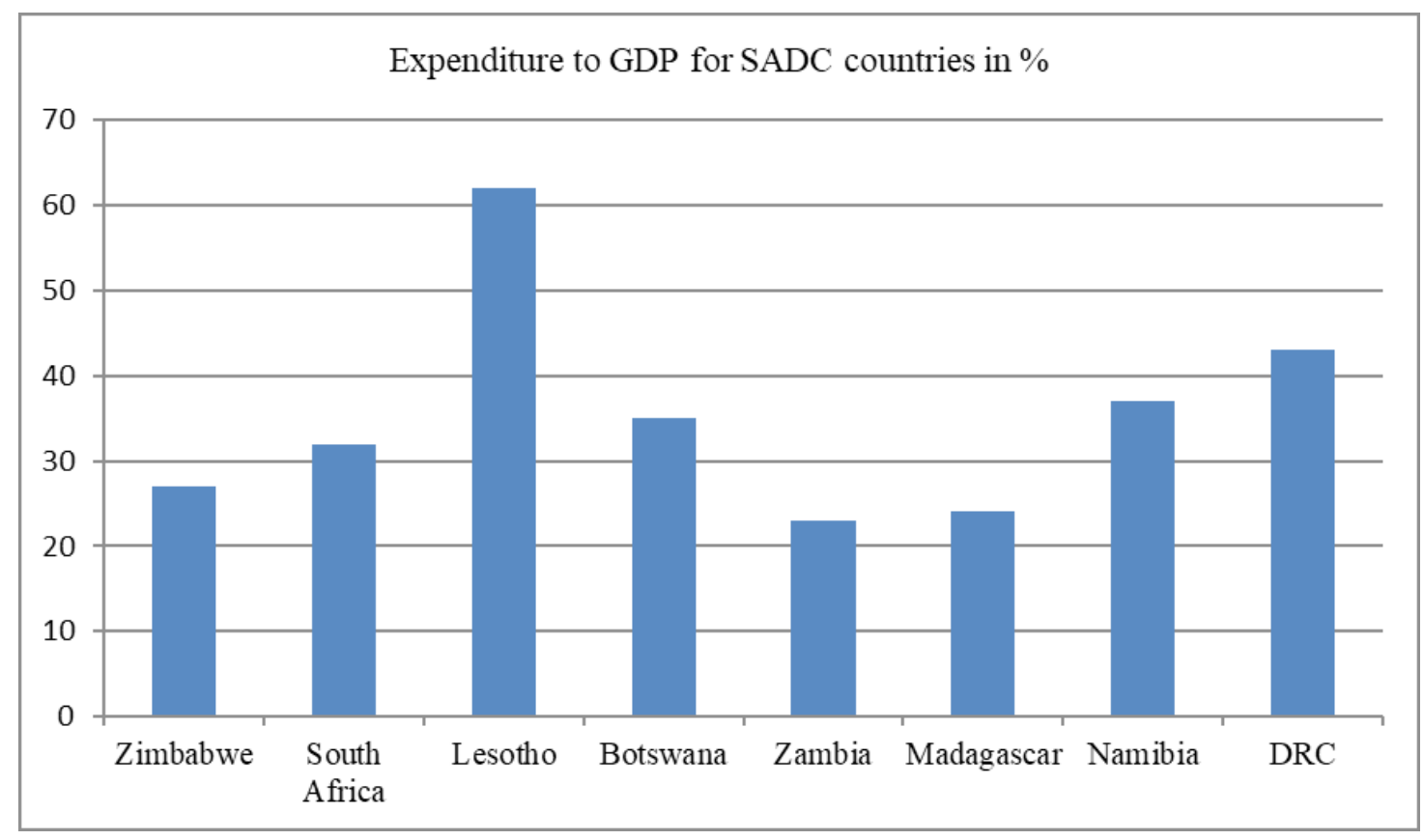

Figure 2. Expenditure to GDP ratio in SADC 
The observed appetite displayed by the Zimbabwean government to spend what it does not have and its ballooned public sector vis a vis economy size has exposed the economy to external shocks, for example from fuel prices. World over spending is not a problem but how the spending is financed marks the difference (Gupta et al., 2005). Zimbabwe can no longer borrow from the World Bank and the International Monetary Fund (IMF) because of its bad credit history and no lines of credit can be opened unless the country clears its debt. That situation has forced the Zimbabwean officials to resort to domestic borrowing through treasury bills and overdrafts from the Reserve Bank of Zimbabwe (RBZ). Domestic borrowing led to money supply growth which led the country to start experiencing inflation which was estimated to be over 200\% in the first quarter of 2019 (World Bank, 2019).

The problem with Zimbabwe's government expenditure is the funding of recurrent expenditure as opposed to key productive sectors. According to Egwaikhide et al. (2002), most developing economies rely on government expenditure to kick start economic growth especially during recessions but that is only achievable if the spending is channeled towards productive sectors of the economy to create demand and jobs.

\section{LITERATURE REVIEW}

\subsection{Theoretical framework}

The development model by Musgrave and Rostow argue that government expenditure must respond according to economic growth and development in a country (Musgrave \& Rostow, 1969). The model treats government expenditure as a function of the size of economic growth. Hence, government expenditure is expected to be higher at the early stages of economic development (Okoro, 2010). According to the development model, government expenditure is expected to be higher in the early stages of development, mostly because the state must make sure that there is necessary infrastructure for the convenience of industrialization in a country. The theory is based on the argument that the moment an economy moves to the next stage of development, government spending decreases. The next or second stage of production where government expenditure is expected to fall is assumed to be characterized by rapid economic growth. In the second stage, private investment and activities are activities are expected to rise causing rapid growth and increase in private saving. The last stage of the development model by Musgrave and Rostow argues that, because private investment and activities have risen, government spending must increase to compliment the private sector through providing for example, more security and education (Musgrave, 1969).

On the other hand, classical economists believed that the role of the government must be limited to only providing a conducive investment climate for the private sector to thrive. According to the classical theory, government activities in the economy must be limited to provision of security (defense) guaranteeing law and order for the efficient operation of the private sector. The argument of the classical theory was that any government involvement outside providing security will cause distortions in the economy and make the economy prone to economic crises. The classical theory is not too distant from the work of Adams based on the argument that government spending and output should always grow with the same proportion. The work of Adams inspired the work of Wagner early in the 20th century growing literature of the relationship between government expenditure and macroeconomic stability. Wagner argued that the progress in the society is what makes government expenditure to be inevitable. If society is doing well then government has to raise its spending to compliment the society. Wagner's law posits that; the activities of the state must increase if the progress achieved by the society is not to be reversed. The state must expand its budget on defense, power, social services, communication and education since thy are necessary for smooth running of the economy.

Lastly, Keynes managed to turn around economic assumptions and beliefs about government expenditure (Keynes, 1963). The classists and Wagner's law believed that government expenditure must only be raise to compliment private sector activities not the other way round (Wagner, 1883). The Keynesian theory believed that government spending must be increased especially during a recession to bring back the economy to the steady state. Keynes argued that people should not wait for the economy to bring itself to normalcy or wait for the long-run for the economy to adjust but the government must increase its spending. The Keynesian theory only emphasizes 
increase in government expenditure in during a recession meaning that when the economy recovers and there is prosperity, the government must cut back on expenditure. Keynes argued that waiting for the long-run for the market to adjust itself to the steady state is dangerous because in the long-run we will all be dead.

\subsection{Government expenditure and macroeconomic stability}

In examining the literature on the relationship between government expenditure and macroeconomic stability, the author starts by looking at the work of Fatas and Mihov. Fatas and Mihov (1999) examined if there is a relationship between government size and business cycle volatility in the OECD countries using data from 1960 to 1997. The findings of their study showed that economies with large governments have a stabilizing impact on output leading them to conclude that government size and output volatility are negatively correlated.

Fan and Rao (2003) showed that the trend of government spending is important in achieving macroeconomic stability. The scholars used a cross-country study to find that government spending on health and agriculture is good in Africa. However, expenditure on education and agriculture can facilitate economic growth in Asia. As for Latin America it is spending on health that promotes economic growth. Another study by Attari and Javed (2013) for Pakistan found that a relationship between government recurrent expenditure and economic growth was negative. Other studies that found a negative relationship between government expenditure and output include Chamorro-narvaez (2012) and Mohanty and Zampolli (2009). On the contrary, Okoro (2010) found a positive effect of government capital expenditure on gross domestic product (GDP) in the long-run. However, the effect of recurrent spending had a negative effect on output.

Audu (2012) analyzed a relationship between economic growth and fiscal policy in Nigeria using data spanning 1970 to 2010. The study employed a co-integration error correction mechanism and the results revealed that there is an existent relationship between exports ad GDP. The author concluded that fiscal policies do have significant effects on output in the Nigerian economy. Using an error correction methodology as well, Risquete and Ramajo (2015) analyzed fiscal policy effects on the Spanish economy is using annual data from 1978 to 2009. Results from a Vector-autoregressive Error Correction Mechanism (VECM) showed that the Spanish economy (GDP) responds positively to total government receipts. To the contrary, total government spending is positive in the short-run but negative starting from the medium term to the long-run.

Using annual data from 1994 to 2007, $\mathrm{Li}$ (2010) analyzed the relationship between output volatility and government expenditure in China. Results from an ordinary least squares (OLS) regression indicated that output fluctuations are not reduced by fiscal transfers and provincial budgetary revenues under tax assignment system. It showed that in huge contrasts with the experiences of most developed countries like China central and provincial authorities do not use public expenditure as a stabilizing too to deal with economic shocks.

Miron (2010) also examined the relationship between government expenditure and the findings point that large recurrent government expenditure is counterproductive. The conclusion of the author was that smaller governments are better for growth. On the other hand, a study by Saville (2008) concurs with Miron (2010) on the argument that they characterize government as a huge parasite which draws much from the economy when an economy is doing well but draws little when the economy is in doldrums. Saville argued that government expenditure during a recession is more likely to make the situation worse as opposed to stimulating it like what the Keynesian theory says. Khan (2011) analyzed the effects of fiscal policy on economic growth for the Pakistan economy. The scholar used time series data from 1980-2009 estimating the Johansen co-integration technique, Error Correction Model (ECM) and Granger causality. The findings of that study revealed that fiscal policy has a significant effect of economic growth and sustainability in Pakistan. However, fiscal policy is more useful in the long-run whilst the short-run manipulated interest rate brings sustained economic growth.

Ismail and Hussain (2012) examined the effect of government expenditure on inflation, output and employment in Pakistan with data spanning 1971 to 2009. The findings of the study points to the fact that neither development spending nor recurrent spending are led by changes in economic activity and that reasons why expenditure continued to be insignificant for macroeconomic variables for employment and output. The conclusion of the study was that loans should not be taken when there is no recommendation of cost and benefit analysis. 


\section{METHODOLOGY}

\subsection{Data Description}

We rely on an annual time series dataset observed between 1981 and 2019 guided by data availability from the World Development Indicators and Our World in Data which are our primary sources of data. This sampling period yields a total of 39 observations which we believe is reasonably long enough to establish the potential effect of government expenditure on macroeconomic stability. The first methodological step involves the measurement of macroeconomic instability and the subsequent section exists for this purpose.

\subsection{Measuring Macroeconomic Instability}

Measuring macroeconomic stability (or lack thereof) is far from easy empirically and the controversy is over two decades old. Much of the debate revolves around the appropriate proxy of macroeconomic instability with earlier studies such as Fischer (1992) preferring instability measured based on inflation. Others such as Cariolle and Goujon (2015) have recently proxied macroeconomic stability using instability in export revenue. UNCTAD (2016) has long challenged the notion of proxying macroeconomic instability based on one indicator however suggesting instead the joint use of a wide array of macroeconomic indicators. Motivated by this recommendation, Haroon and Jehan (2020) recently compute a macroeconomic instability index based on terms of trade, inflation rate, unemployment rate and real exchange rate. Their macroeconomic index is computed as follows:

$$
\begin{aligned}
& M I=\alpha\left[\frac{\left(T O T_{i t}-T O T_{i \min }\right)}{\left(T O T_{i \max }-T O T_{i \min }\right)}\right]+\beta\left[\frac{\left(I n f_{i t}-I n f_{i \min }\right)}{\left(I n f_{i \max }-I n f_{i \min }\right)}\right]+ \\
& +\gamma\left[\frac{\left(U N_{i t}-U N_{i \min }\right)}{\left(U N_{i \max }-U N_{i \min }\right)}\right]+\lambda\left[\frac{\left(R E R_{i t}-R E R_{i \min }\right)}{\left(R E R_{i \max }-R E R_{i \min }\right)}\right],
\end{aligned}
$$

where $M I$ is macroeconomic instability, TOT is terms of trade, Inf is the inflation rate, $U N$ is unemployment, $R E R$ is the real exchange rate, min is minimum, and max is maximum. While the intend is plausible, the procedure is less so. They claim to use standard deviations $(\alpha, \beta, \gamma$ and $\lambda)$ as weights which is hard to comprehend not only because the procedure of ensuring that $\alpha, \beta, \gamma$ and $\lambda$ sums up to one is vague and not explicitly explained but also because the four indicators are measured in completely different units. Cognisance of this important limitation, we rely instead on the principal component analysis which constructs weights in a much more systematic way. In particular, it studies the correlations among the variables and then determine the weights based on the contribution of each variable towards the variation of the overall component.

From their selected variables, we retain TOT and the inflation rate and drop the unemployment rate and the real exchange rate due to data unavailability. Unemployment in particular is only available from 1991 when our starting sampling period is 1982. On the other hand, Zimbabwe completely dollarized in 2009 and therefore the country did not have an official local currency for the best part of the period after 2009. We replace these two variables with five equally important macroeconomic indicators namely output gap computed using the HodrickPrescott filter method, current account balance (CAB) (as percentage of GDP), public debt (as a percentage of GDP), IMF loans and outward foreign direct investment (as a percentage of GDP). Selection of these additional indicators is justified by two considerations. Firstly, there is hardly any economy in which the authorities would ideally not prefer having less of these. Secondly, it is hard to think of any of these indicators as a characteristic of a stable economy. Governments for example that resort to IMF loans are in the majority of cases already facing economic turmoil and chronic macroeconomic instability. Outward foreign direct investment in the African context mostly signals capital outflows owing to an unstable and uncertain economic environment. Output gap, public debt and current account balance are self-explanatory. Their increase is mostly accompanied by macroeconomic imbalances. 
The principal factor analysis (PFA, hereafter), used here to create a macroeconomic instability index, gets used in many cases to compress data to come up with a small set of variables (preferably uncorrelated) from a large set of variables (most of which are correlated to each other). Therefore, the objective is to create a macroeconomic index (M), which is achieve in two broad steps in this study. In the first step, the index is calculated from the following specification.

$$
\begin{aligned}
& M_{t}=\omega_{1} \text { Inflation }_{t}+\omega_{2} \text { TOT }_{t}+\omega_{3} \text { Output_Gap }_{t}+\omega_{4} \text { Public Dept }_{t}+ \\
& +\omega_{5} \text { Outward_FDI } \\
& +
\end{aligned}
$$

where $\omega$ are the weights.

At this stage, several points are noteworthy. Firstly, we applied the Kaiser test to determine which factors are meaningful. With this test, we essentially retain components that enter with an eigenvalue of 1 or greater. Secondly, we proceeded to apply Varimax rotation in order to maximize the sum of the variance of the squared loadings, where "loadings" refer to the correlations between variables and the component factors. This essentially facilitates high factor loadings for a smaller number of variables as each variable will load onto one factor as highly as possible while loading onto the second factor as little as possible. We then thirdly tested the groupings using the Cronbach's $\alpha$ before computing the overall index. From the computed index, the macroeconomic instability (MI) index is then calculated as follows.

$M I=\frac{\left(M_{t}-M_{\text {min }}\right)}{\left(M_{\text {max }}-M_{\text {min }}\right)}$,

where $M I$ denotes macroeconomic instability, and the remaining variables are as defined before.

Measured in this way, an increase in this index represents an increase in instability. The study then continues using this index as the dependent variable of interest in the next section.

\subsection{Estimation Technique and process}

To test the Keynesian proposition of a possible link between government expenditure and macroeconomic stability, we resort to a system of equations approach in a bid to offset the potential endogeneity problem emanating from simultaneity. It is widely acknowledged that fiscal decisions are in the majority of cases a reaction to macroeconomic instability, which means changes in government expenditure might be endogenous. A system of equations approach, the vector autoregression method in particular, allows us to treat both variables as endogenous. To avoid or at least reduce the possibility of an omitted variable bias, we include trade (exports plus imports as a percentage of GDP) in the system. The inclusion of a trade variable is crucial in so far as it controls for a channel through which external instability feeds into the domestic economy in the absence of an exchange rate variable.

As a precondition in time series, we first evaluated the underlying data generating process using three non-stationarity tests namely the Augmented Dickey Fuller (ADF), Phillips-Perron (PP) and the Break-Point unit root tests. In all cases, the null hypothesis is of a unit root and it is rejected if the corresponding probability value exceeds the $10 \%$ maximum level of significance.

Having evaluated the underlying data generating process, then next step will involve checking the possibility of a cointegrating relationship if the trio is non-stationary and integrated of the same order. To achieve this, we will consider the Johansen approach which is based on the following specification. 


$$
\begin{aligned}
& \Delta X_{t}=\sum_{i=1}^{p-1} \Gamma_{i} \Delta X_{t-i}+\prod X_{t-1}+\varepsilon_{t}, \\
& \varepsilon_{t} \mid \Omega_{t-1} \sim \operatorname{dist}\left(0, H_{t}\right), \\
& t=1,2, \ldots, T
\end{aligned}
$$

where $X$ is a $3 \cdot 1$ vector of our macroeconomic instability index (MI), government expenditure (G) (as a percentage of GDP) and trade (TR), respectively, $\Delta$ is the first difference operator, $\varepsilon_{t}$ is a $3 \cdot 1$ vector of residuals characterised by a distribution that possess a zero mean and time-varying covariance matrix, $H_{t}$. The VECM specification comprises both short-and-long run information in $\Gamma i$ and $\Pi$, respectively. We then consider two likelihood ratio tests namely the trace $\left(\lambda_{\text {trace }}\right)$ and maximum eigen $\left(\lambda_{\max }\right.$ statistics in order to determine the presence of co-integration between the two series.

$$
\begin{aligned}
& \lambda_{\text {trace }}(r)=-T \sum_{i=r+1}^{n} \operatorname{In}\left(1-\hat{\lambda}_{i}\right), \\
& \lambda_{\max }(r, r+1)=-T \sum_{i=r+1}^{n} \operatorname{In}\left(1-\hat{\lambda}_{r+i}\right),
\end{aligned}
$$

where $\lambda_{i}$ are the eigen values obtained from the estimate of the $\Pi$ matrix and $T$ is the maximum number of time series observations. The $\lambda_{\text {trace }}$ tests the null hypothesis that there are at most $r$ cointegrating vectors, against the alternative that the number of cointegrating vectors is greater than $r$. The $\lambda_{\max }$ considers the null hypothesis that the number of cointegrating vectors is $r$, against the alternative of $r+1$ If rank $(\Pi)=0$, then $\Pi$ is $2 \cdot 2$ zero matrix implying no cointegration relationship between macroeconomic instability and government expenditure. In this case the VECM reduces to a VAR model in first differences. If $\Pi$ has a full rank, that is rank $(\Pi)=2$, then both macroeconomic instability and government expenditure are $\mathrm{I}(0)$ and the appropriate modelling strategy is to estimate a VAR model in levels. If $\Pi$ has a reduced rank, that is rank $(\Pi)=1$, then there is a single cointegrating relationship between macroeconomic instability and government expenditure which will be given by any row of matrix $\Pi$ and the expression $\prod X_{t-1}$ will be the error correction term. In this case, $\Pi$ can be factored into two separate matrices $\alpha$ and $\beta$. These matrices are of dimensions $2 \cdot 1$ where 1 is the rank of $\Pi$, such as $\Pi=\alpha \beta$, where $\beta$ ' captures cointegrating parameters and $\alpha$ embeds error-correction coefficients measuring the speed of convergence.

If government expenditure and macroeconomic instability are cointegrated, then there must be at least a unidirectional causality (Granger, 1988). As a result, we will consider the standard causality tests within the auspices of a VECM framework, and it will be based on the following specifications.

$$
\begin{aligned}
& \Delta M I_{t}=\sum_{i=1}^{p-1} \alpha_{M, i} \Delta M I_{t-i}+\sum_{i=1}^{p-1} b_{M, i} \Delta G_{t-i}+\theta_{M} E C T_{t-1}+\varepsilon_{M, t,} \\
& \varepsilon_{t} \mid \Omega_{t-1} \sim \operatorname{dist}\left(0, H_{t}\right), \\
& \Delta G_{t}=\sum_{i=1}^{p-1} \alpha_{G, i} \Delta I M_{t-i}+\sum_{i=1}^{p-1} b_{G, i} \Delta G_{t-i}+\theta_{M} E C T_{t-1}+\varepsilon_{G, t},
\end{aligned}
$$

where $M I$ and $G$ are as defined before and ECT is the error correction term. A Wald test is conducted to test the joint significance of $b_{M}$ in (7) and $\alpha_{G}$ in (8). In each case, causality exists if the null hypothesis is rejected. Note that (7) and (8) reduce to,

$$
\Delta M I_{t}=\sum_{i=1}^{p-1} \alpha_{M, i} \Delta I M_{t-i}+\sum_{i=1}^{p-1} b_{M, i} \Delta G_{t-i}+\varepsilon_{M, t}
$$


$\varepsilon_{t} \mid \Omega_{t-1} \sim \operatorname{dist}\left(0, H_{t}\right)$,

$\Delta G_{t}=\sum_{i=1}^{p-1} \alpha_{G, i} \Delta I M_{t-i}+\sum_{i=1}^{p-1} b_{G, i} \Delta G_{t-i}+\varepsilon_{G, t}$,

unless $\mathrm{G}$ and $\mathrm{MI}$ are found to be cointegrated. Post estimation, a battery of diagnostic tests will be considered that range from serial correlation tests to model specification, heteroscedasticity, residual normality, and parameter stability tests. For robustness checks, estimations from two additional methods were also considered, namely the dynamic ordinary least squares (DOLS) and the fully modified ordinary least squares (FMOLS).

\section{RESULTS AND DISCUSSION}

Since the primary contribution is embedded in computing a macroeconomic index, we start with results from the principal factor analysis. Table 1 contains the unrotated principal component factors and it shows that the first three factors whose Eigenvalues are greater than 1 cumulatively explain about $75 \%$ of the total variance. Based on the Kaiser criterion, we retain these three factors.

Table 1. Unrotated Principal-component factors

Source: Own computation.

\begin{tabular}{l|c|c|c|c}
\hline \multicolumn{1}{c|}{ Factor } & Eigenvalue & Difference & Proportion & Cumulative \\
\hline Factor1 & 2.39005 & 0.86791 & 0.3414 & 0.3414 \\
Factor2 & 1.52214 & 0.20153 & 0.2174 & 0.5589 \\
Factor3 & 1.32061 & 0.63299 & 0.1887 & 0.7475 \\
Factor4 & 0.68762 & 0.15345 & 0.0982 & 0.8458 \\
Factor5 & 0.53417 & 0.18381 & 0.0763 & 0.9221 \\
Factor6 & 0.35036 & 0.15532 & 0.0501 & 0.9721 \\
Factor7 & 0.19505 & - & 0.0279 & 1 \\
\hline
\end{tabular}

Note: LR test: independent vs. saturated: chi2(21) $=75.80$, prob $>$ chi2 $=0.0000$, retained factors $=3$, number of parameters $=18$.

Table 2 proceeds with factor loadings and unique variances. Factor loadings represent weights and correlations of a variable and the factor. If the load is higher, that is an indication that the defining the factor's dimensionality is relevant. Here as indicated above, the first three factors are retained based on Eigenvalues above 1. From Table 2, inflation, use of IMF loans, outward FDI and terms of trade load highly in the first factor while debt, output gap and current account balance load highly in the second factor. Uniqueness is the variance that is "unique" to the variable and not shared with other variables. In this case, for example, results indicate that $24.34 \%$ of the variance in inflation "inf" is not shared with other variables in the overall factor model. These values ought to be low, typically below 0.5 as such will imply high relevance of the variable in the factor model. As Table 2 confirms, the uniqueness values are all below 0.5 which is comforting.

Table 2. Factor loadings (pattern matrix) and unique variances

Source: Own computation.

\begin{tabular}{l|c|c|c|c}
\hline \multicolumn{1}{c|}{ Variable } & Factor1 & Factor2 & Factor3 & Uniqueness \\
\hline inf & 0.8558 & 0.0879 & 0.1286 & 0.2434 \\
cab & 0.4229 & 0.7563 & 0.3133 & 0.151 \\
\hline tot & 0.8155 & 0.1507 & 0.1053 & 0.3012 \\
debt & 0.5113 & 0.7453 & 0.0638 & 0.1791 \\
gap & 0.0726 & 0.5656 & -0.6773 & 0.2161 \\
fdi_out & 0.7118 & -0.1253 & -0.1196 & 0.4634 \\
imf_I & 0.8697 & -0.1693 & 0.044 & 0.213 \\
\hline
\end{tabular}


Then varimax was applied from Table 2 to produce orthogonal factors and clearly identify variables to create the macroeconomic index without inter-correlated components. The computed index is displayed in Figure 1 and brings two main insights. Firstly, it does confirm that the Zimbabwean economy has experienced a considerable degree of macroeconomic instability since 1981. Secondly and more interestingly, our computed index is able to pick up the unprecedented macroeconomic instability that Zimbabwe went through between 2004 and 2008. During this period, the Southern African economy posted a record-breaking inflation and created a distorted exchange rate market which saw the central bank of Zimbabwe ditch the local currency in favour of a basket of multiple currencies. This brought back confidence in the economy and an improvement in economic stability which Figure 1 clearly confirms. In addition, the index is able to confirm the recent and post 2013 economic instability that was characterized by foreign currency shortages in banks and financial institutions. By picking up well known episodes of macroeconomic instability of this sort, we can safely proceed with our analysis with a considerable level of confidence in our computed macroeconomic instability index.

Next, results from the three non-stationarity tests are presented meant to provide a picture of the underlying data generating process. As Table 3 shows, the null hypothesis of a unit root cannot be rejected in levels. It is after first differencing that we are able to reject the null of a unit root suggesting that the trio is integrated of order one. With this result, you can safely proceed to checking possible cointegration using the Johansen test.

Table 3. Non-Stationarity Test Results

\begin{tabular}{|c|c|c|c|c|c|c|c|}
\hline & \multicolumn{2}{|c|}{ ADF } & \multicolumn{2}{|c|}{ PP } & \multicolumn{2}{|c|}{ BP } & \multirow{2}{*}{$\begin{array}{c}\text { Order of } \\
\text { integration }\end{array}$} \\
\hline & Levels & $\Delta$ & Levels & $\Delta$ & Levels & $\Delta$ & \\
\hline $\mathrm{Ml}$ & 2.138 & $6.260^{*}$ & 2.158 & $6.261^{*}$ & 2.764 & $6.779^{*}$ & $I(1)$ \\
\hline G & 1.727 & $5.990^{*}$ & 1.973 & $6.013^{*}$ & 2.520 & $7.128^{*}$ & $I(1)$ \\
\hline TR & 2.213 & $8.966^{*}$ & 2.027 & $9.213^{*}$ & 2.696 & $9.782^{*}$ & $\mathrm{I}(1)$ \\
\hline
\end{tabular}

Note: For ADF and PP tests, ${ }^{*}=$ MacKinnon (1996) one-sided p-values; for BP, ${ }^{*}=$ Vogelsang (1993) asymptotic one-sided p-values. In all cases, the tests are based on specifications with intercept and no trend.

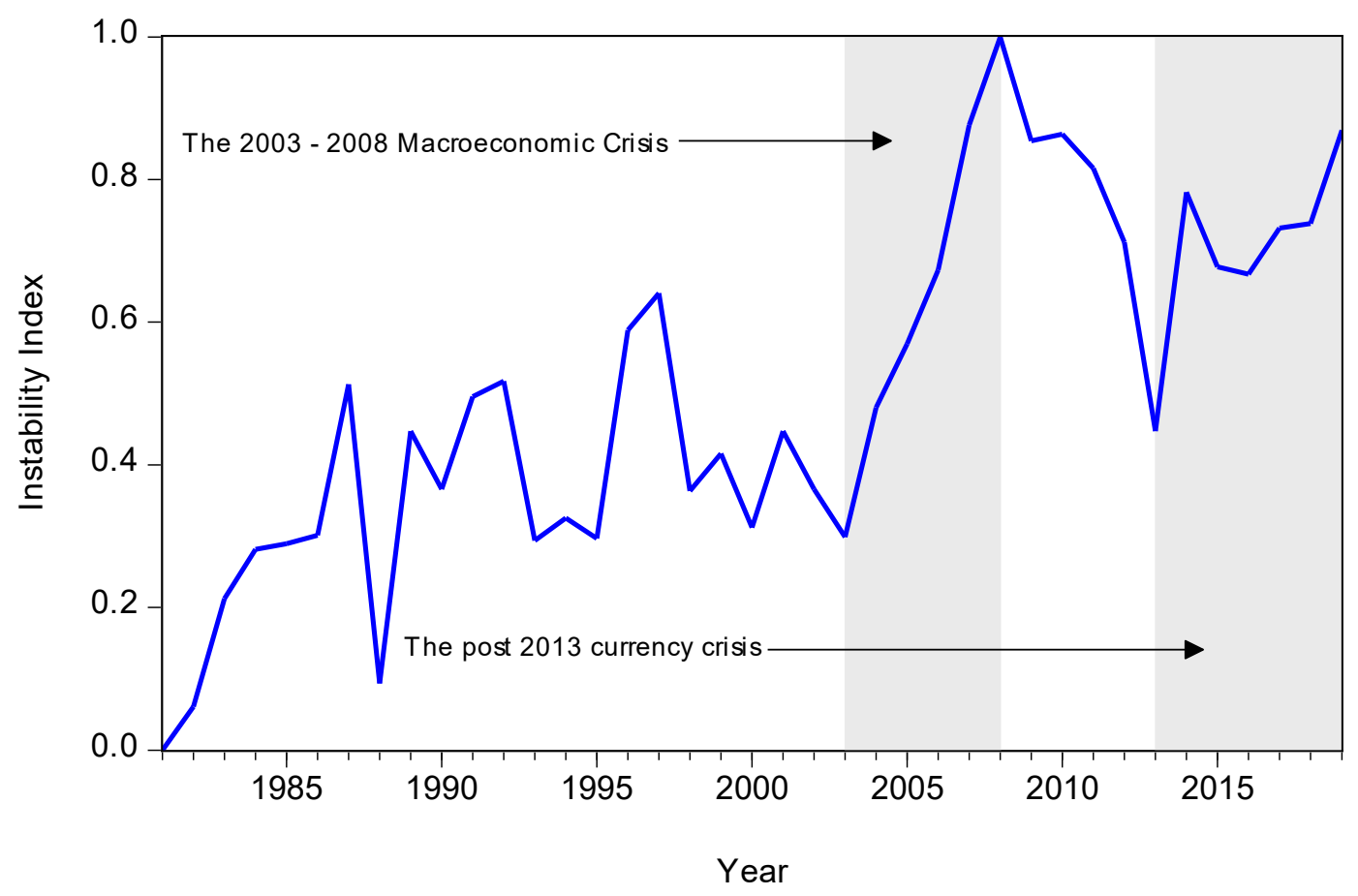

Figure 3. Macroeconomic Instability Index in Zimbabwe 
Since the Johansen test is sensitive to the optimum lag, Table 3 presents results from various lag selection criterions. As the results confirm, three of the five criterions pick 5 as the optimum lag.

Table 4. Optimum Lag Length

\begin{tabular}{c|c|c|c|c|c|c}
\hline Lag & LogL & LR & FPE & AIC & SC & HQ \\
\hline 1 & -194.5801 & NA & 31.91415 & 11.9753 & $12.37934^{*}$ & $12.11309^{*}$ \\
2 & -188.5457 & 9.938982 & 38.37163 & 12.14975 & 12.95782 & 12.42532 \\
3 & -178.2571 & 15.13033 & 36.56359 & 12.07395 & 13.28606 & 12.48731 \\
4 & -168.605 & 12.49099 & 37.22962 & 12.03559 & 13.65173 & 12.58674 \\
5 & -153.2061 & $17.21049^{*}$ & $28.23710^{*}$ & $11.65918^{*}$ & 13.67937 & 12.34812 \\
\hline
\end{tabular}

Note: * denotes lag order chosen by the criterion; LR: sequential modified LR test statistic (each test at $5 \%$ level); FPE: final prediction error; AIC: Akaike information criterion; SC: Schwarz information criterion; HQ: Hannan-Quinn information criterion.

You can proceed to the Johansen test results. As evidently presented in Table 5, the null hypothesis of no cointegration is strongly rejected both by the trace and eigen value statistics. The next hypothesis is of at most 1 cointegrating equation and clearly, there is no sufficient statistical evidence to reject this null hypothesis at $5 \%$ level of significance. This means we have evidence of at most one cointegrating equation in our system which paves way for a vector error correction model so that short run dynamics can be reconciled with long run information via an error correction mechanism. In other words, we have evidence that macroeconomic instability, government expenditure and trade are cointegrated and therefore by implication possess a long run relationship.

Table 5. Johansen Cointegration Test

\begin{tabular}{|c|c|c|c|c|}
\hline \multicolumn{5}{|c|}{ Unrestricted Cointegration Rank Test (Trace) } \\
\hline $\begin{array}{l}\text { Hypothesized No. of } \\
\text { CE(s) }\end{array}$ & Eigenvalue & Trace Statistic & 0.05 Critical Value & Prob.** \\
\hline None * & 0.518375 & 34.51989 & 29.79707 & 0.0133 \\
\hline At most 1 & 0.247739 & 9.679828 & 15.49471 & 0.3062 \\
\hline At most 2 & $2.90 \mathrm{E}-05$ & 0.000988 & 3.841466 & 0.9751 \\
\hline \multicolumn{5}{|c|}{ Unrestricted Cointegration Rank Test (Maximum Eigenvalue) } \\
\hline $\begin{array}{l}\text { Hypothesized No. of } \\
\text { CE(s) }\end{array}$ & Eigenvalue & Max-Eigen Statistic & 0.05 Critical Value & Prob.** \\
\hline None * & 0.518375 & 24.84007 & 21.13162 & 0.0143 \\
\hline At most 1 & 0.247739 & 9.678841 & 14.2646 & 0.2339 \\
\hline At most 2 & $2.90 \mathrm{E}-05$ & 0.000988 & 3.841466 & 0.9751 \\
\hline
\end{tabular}

Note: trace test reflects 1 cointegrating eqn(s) at the $5 \%$ level; * indicate rejection of the hypothesis at the $5 \%$ level; ${ }^{* *}$ MacKinnon-Haug-Michelis (1999) p-values. Max-eigenvalue test denotes 1 cointegrating eqn(s) at the 0.05 level; * means rejection of the hypothesis at the $5 \%$ level; ${ }^{* *}$ MacKinnon-Haug-Michelis (1999) p-values.

At this stage, the VECM estimates were considered, as well as the dynamic ordinary least squares (DOLS) and fully modified ordinary least squares (FMOLS) estimates for robustness purposes. As a standard practice, the VECM was estimated with 4 lags (5-1) and the estimated cointegrated vector was multiplied by -1 for a straightforward interpretation. Table 6 presents these results, and the table is portioned into three columns. The first is the VECM cointegrating vector with its corresponding error correction term. The second variant contains the DOLS estimates which is based on 1 lead and 1 lag. The third and final variant contains the FMOLS estimates. As the results clearly show, the connection between government expenditure and macroeconomic stability predicted by Keynesian followers is not existent as the relationship is rightly negative but statistically insignificant. This result is true across all the three regression variants and it implies that the general rise in government expenditure observed in Zimbabwe between 1981 and 2019 hardly came with any stabilising effect during the same period in the Southern African economy.

Meanwhile, trade enters with a negative and statistically significant effect which implies a stabilising effect of global trade on the Zimbabwean economy. This is not surprising given a plethora of studies documenting a stabilising effect of trade on output volatility in developing countries. Imports in particular tend to bridge and cushion the domestic demand-supply gap and shock, respectively, a channel which is plausible given Zimbabwe's experience in the past three years. The economy witnessed recurrent and persistent negative productivity shocks and macroeconomic instability that saw a massive proliferation of imports. 
The error correction term which measures the speed of adjustment is negative as expected and statistically significant. The significantly negative sign provides some reassurance of a cointegrating equation in so far as it suggests that the estimated model reverts back to the equilibrium position in the event of a short run discrepancy. The size of the coefficient in particular indicates that roughly a third of the short-run disequilibrium is corrected each year.

Table 6. Macro-stability and Government Expenditure Long run estimates

\begin{tabular}{|c|c|c|c|}
\hline Cointegrating Eq: & CointEq1-VECM & DOLS & FMOLS \\
\hline \multirow{2}{*}{ G } & -0.118702 & -0.006 & -0.007 \\
\hline & $(0.25121)$ & $(0.009)$ & $(0.006)$ \\
\hline \multirow{2}{*}{ TR } & $-0.261489^{\star \star \star}$ & $-0.012^{* *}$ & $-0.015^{* * *}$ \\
\hline & $(0.06554)$ & $(0.005)$ & $(0.005)$ \\
\hline \multirow{2}{*}{ C } & -12.44018 & 0.6502 & 0.842 \\
\hline & - & $(0.504)$ & $(0.478)$ \\
\hline \multirow{2}{*}{ CointEq1 } & $-0.312927^{* * *}$ & - & - \\
\hline & $(0.00772)$ & - & - \\
\hline Ramsey RESET & - & 0.3718 & - \\
\hline Breusch-Godfrey & - & 0.3527 & - \\
\hline Jarque-Bera & - & 0.8183 & 0.5273 \\
\hline Breusch-Pagan & - & 0.1521 & - \\
\hline Hansen instability & - & $>0.2$ & $>0.2$ \\
\hline \multirow[t]{2}{*}{ Engle-Granger } & - & 0.0073 & 0.0271 \\
\hline & $p<0.01, p<0.05 \& p<$ & 0.01 , respectively. & \\
\hline
\end{tabular}

Note: ${ }^{*}, * * * * *$ denote

Figures in parentheses are standard errors. The DOLS was estimated with 1 lead and 1 lag. Results of these leads and lags are not reported as they nuisance parameters whose tenet is to eliminate endogeneity according to Stock and Watson (1991).

The estimated VECM was free from residual non-normality and dynamic instability as all roots lied inside the unit circle. Results of these diagnostic tests are attached in appendix in the interest of brevity. Regarding the DOLS results which appear on the lower part of Table 6 , the estimated model is clearly well specified, free from both heteroscedasticity, autocorrelation and residual non-normality which is reassuring. Interestingly, the Hansen instability and Engle-Granger tests for cointegration are firmly in support of the Johansen testing so far as they confirm the presence of a cointegrating equation.

Next, the results of the Granger causality tests are then examined to infer the direction of causality presented in Table 7. Of interest here is the two upper specifications in which macroeconomic instability (MI) and government expenditure are the dependent variables, respectively. Evidently, there is no sufficient evidence to reject the null hypothesis that government expenditure $(\mathrm{G})$ does not granger cause macroeconomic instability. Instead, it is trade (TR) that seems to have a causal effect on macroeconomic instability. Interestingly in the specification in which $G$ is the dependent variable, the null hypothesis that macroeconomic instability does not granger cause government spending is strongly rejected at 1 percent level suggesting that causality runs from macroeconomic instability to fiscal spending and not the other way round. This observation supports our prior methodological suspicion that fiscal policy decisions tend to be reactive and not proactive in Zimbabwe. Further to this observation, evidence suggests however that such reactionary fiscal interventions in form of increased government spending have hardly stabilized the Zimbabwean economy during the study period. 
Table 7. Granger Causality

\begin{tabular}{|c|c|c|c|}
\hline \multicolumn{4}{|c|}{ Dependent variable: $\mathrm{D}(\mathrm{MI})$} \\
\hline Excluded & Chi-sq & $\overline{D f}$ & Prob. \\
\hline$D(G)$ & 3.977525 & 4 & 0.4091 \\
\hline $\mathrm{D}(\mathrm{TR})$ & 66.01597 & 4 & 0.0000 \\
\hline All & 9.04005 & 8 & 0.3389 \\
\hline \multicolumn{4}{|c|}{ Dependent variable: $\mathbf{D}(\mathbf{G})$} \\
\hline Excluded & Chi-sq & Df & Prob. \\
\hline $\mathrm{D}(\mathrm{MI})$ & 8.846134 & 4 & 0.0651 \\
\hline $\mathrm{D}(\mathrm{TR})$ & 6.945464 & 4 & 0.1388 \\
\hline Aill & 11.74588 & 8 & 0.1629 \\
\hline \multicolumn{4}{|c|}{ Dependent variable: $\mathrm{D}(\mathrm{TR})$} \\
\hline Excluded & Chi-sq & Df & Prob. \\
\hline $\mathrm{D}(\mathrm{MI})$ & 37.02555 & 4 & 0.0000 \\
\hline $\mathrm{D}(\mathrm{G})$ & 44.91735 & 4 & 0.0000 \\
\hline All & 56.67579 & 8 & 0.0000 \\
\hline
\end{tabular}

Lastly Table 8 demonstrates the insignificance of government expenditure on variations in Zimbabwe's macroeconomic instability using the variance decomposition function for a 25 -year period. Unsurprisingly, government expenditure $(\mathrm{G})$ only account for $1.4 \%$ of variation in Zimbabwe's macroeconomic instability. This is revealing for an economy that has been well known for heightened fiscal spending (averaging nearly a quarter of GDP between 1981 and 2019) as an effort to achieve macroeconomic stability. Zimbabwe particularly turned to fiscal policy as their primary stabilization instrument post 2009 owing to a combination of the multicurrency regime and the deterioration of financial conditions which rendered the monetary policy virtually ineffective. There is hardly any evidence here that the increasing reliance on fiscal expenditure affected macroeconomic instability. In theory, one would expect a strong connection between countercyclical fiscal policy responses to cushion macroeconomic volatility via both the demand and supply side. The result obtained challenges this notion advanced by Gali (1994) and Kumhof and Laxton (2009) which broadly falls within the common Keynesian narrative. Neither the estimated model not the variance decomposition function substantiates this narrative. Rather, evidence was found that much of Zimbabwe's macroeconomic instability is explained by own shocks and trade dynamics, which account for $82 \%$ and $17 \%$, respective.

Table 8. Variance decomposition of MI in Zimbabwe

\begin{tabular}{|c|c|c|c|c|}
\hline Period & S.E. & MI & $\mathbf{G}$ & TR \\
\hline 1 & 0.153471 & 100 & 0 & 0 \\
\hline 2 & 0.190077 & 98.35938 & 0.713331 & 0.927287 \\
\hline 3 & 0.23814 & 89.59149 & 3.778508 & 6.630004 \\
\hline 4 & 0.288593 & 87.35981 & 3.670814 & 8.969371 \\
\hline 5 & 0.348985 & 86.11609 & 2.622064 & 11.26185 \\
\hline 6 & 0.415299 & 85.16585 & 2.018168 & 12.81598 \\
\hline 7 & 0.476717 & 83.56626 & 1.665826 & 14.76791 \\
\hline 8 & 0.518351 & 82.5528 & 1.525278 & 15.92192 \\
\hline 9 & 0.54978 & 82.37108 & 1.537503 & 16.09141 \\
\hline 10 & 0.576606 & 82.74023 & 1.56061 & 15.69916 \\
\hline 11 & 0.600162 & 82.72418 & 1.598053 & 15.67777 \\
\hline 12 & 0.626432 & 82.64584 & 1.644661 & 15.7095 \\
\hline 13 & 0.65629 & 82.68647 & 1.606599 & 15.70694 \\
\hline 14 & 0.686894 & 82.56153 & 1.535672 & 15.9028 \\
\hline 15 & 0.717098 & 82.3486 & 1.490057 & 16.16135 \\
\hline 16 & 0.745001 & 82.25923 & 1.454852 & 16.28592 \\
\hline 17 & 0.768774 & 82.20599 & 1.436632 & 16.35738 \\
\hline 18 & 0.790363 & 82.19198 & 1.444849 & 16.36317 \\
\hline 19 & 0.811289 & 82.22943 & 1.45353 & 16.31704 \\
\hline 20 & 0.832029 & 82.23213 & 1.453188 & 16.31468 \\
\hline 21 & 0.853607 & 82.21026 & 1.448789 & 16.34095 \\
\hline 22 & 0.875943 & 82.19156 & 1.433977 & 16.37446 \\
\hline 23 & 0.897849 & 82.14706 & 1.415728 & 16.43721 \\
\hline 24 & 0.918894 & 82.10104 & 1.404376 & 16.49458 \\
\hline 25 & 0.938864 & 82.08563 & 1.397473 & 16.5169 \\
\hline
\end{tabular}


The trivial influence of government expenditure on macroeconomic instability in Zimbabwe could be surprising but somehow supports results in Du Plessis, Smit, and Sturzenegger (2007) where the connection between cyclical fiscal spending and real output dynamics albeit in the context of South Africa. This is a result that may be further unsurprising for at least two additional reasons. Firstly, it is well known that the relationship between countercyclical fiscal spending and macroeconomic stability is a complex one, and one that can only be empirically unveiled. Secondly, while the standard expectation is that of a stabilising effect, there seems to be relevant concerns raised in Debrun and Kapoor (2010) that non-linearities exist in such a way that the adverse effect of high tax rates required to finance the increase in government spending could be offsetting.

\section{CONCLUSION}

Macroeconomic instability has been an issue in Zimbabwe, which peaked between 2004-2008. South Africa's economy hit a world inflation record, forcing the central bank to abolish the sovereign currency in favor of a basket of currencies. During the multicurrency system which was officially launched in 2009, the economy recovered and gained stability which was short-lived before the financial system was hard hit by foreign currency shortages moving back the economy to instability. To get the sense of the macroeconomic instability in Zimbabwe, this paper pursued a sole objective of understanding the effect of government spending on stability. That was done uniquely by creating a macroeconomic instability index using a couple of other macroeconomic variables through the principal component analysis. No statistically significant relationship was found between government expenditure and macroeconomic stability as argued mostly by the Keynesians. However, as per apriori expectations the relationship was found rightly negative. To buttress the Cointegrated-VECM results, we also ran causality tests where we could not find any causality running from government spending to macroeconomic instability but vice versa (causality running from instability to government spending). The causality findings gave us confidence to conclude that government spending in Zimbabwe has always been reactive as opposed to being proactive. This paper recommends the following: Policy makers may need to consider proactive government spending or policies as this helps the economy successfully avoid possible risks such as macroeconomic instability. When policies are proactive rather than reactive, this helps by seizing untapped opportunities, and the economy rightly avoids consequences of reactive governance.

\section{SUGGESTIONS FOR FUTURE RESEARCH}

This contribution of the study was to examine the relationship for the first time in Zimbabwe, as well as to measure the dependent variable. Future researchers can also contribute to this debate by analyzing the effect of the adoption of a multicurrency monetary policy in Zimbabwe on macroeconomic stability in Zimbabwe. It will also be interesting to understand how the macroeconomic stability variable will react to government spending when measured differently than in this study.

\section{AUTHORS CONTRIBUTIONS}

Conceptualization: Harris Maduku, Brian Tavonga Mazorodze.

Formal Analysis: Harris Maduku, Brian Tavonga Mazorodze.

Investigation: Harris Maduku.

Methodology: Harris Maduku, Brian Tavonga Mazorodze.

Writing - original draft: Harris Maduku, Brian Tavonga Mazorodze.

Writing - review \& editing: Brian Tavonga Mazorodze. 


\section{REFERENCES}

1. Attari, M., \& Javed, A. (2013). Inflation, economic growth and government expenditure of Pakistan: 1980-2010. Procedia Economics and Finance, 5, 58-67. https://doi.org/10.1016/S2212-5671(13)00010-5

2. Audu, N. (2012). The Impact of Fiscal Policy on the Nigerian Economy. International Review of Social Sciences and Humanities, 4(1), $142-150$.

3. Barro, R. (1996). Inflation and growth. Review, 78, 153-169. Retrieved from https://research.stlouisfed.org/publications/ review/1996/05/01/inflation-and-growth

4. Cariolle, J., \& Goujon, M. (2015). Measuring macroeconomic instability: A critical survey illustrated with exports series. Journal of Economic Surveys, 29(1), 1-26. https://doi.org/10.1111/joes.12036

5. Chamorro-Narvaez, R. (2012). The Composition of Government Spending and Economic Growth in Developing Countries: The Case of Latin America. OIDA International Journal of Sustainable Development, 5(6), 39-50. Retrieved from https://oidaijsd.com/wp-content/ uploads/2019/04/05-06-04.pdf

6. Debrun, X., \& Kapoor, R. (2010). Fiscal policy and macroeconomic stability: automatic stabilizers work, always and everywhere (IMF Working Papers WP/10/111) (47 p.). International Monetary Fund. Retrieved from https://www.imf.org/external/pubs/ft/wp/2010/ wp10111.pdf

7. Du Plessis, S., Smit, B., \& Sturzenegger, F. (2007). The cyclicality of monetary and fiscal policy in South Africa since 1994. South African Journal of Economics, 75(3), 391-411. https://doi.org/10.1111/j.1813-6982.2007.00128.x

8. Egwaikhide, F., Oyeranti O., Ayodele, O., \& Tchokote, J. (2002). Causality between Budget Deficit and the Current Account Balance in African Countries. West African Journal of Monetary and Economic Integration, 2, 10-41.

9. Fan, S., \& Rao, N. (2003). Public Spending in developing Countries: Trends, Determination and Impact (EPTD Discussion Paper No.99). Washington: International Food Policy Research Institute. Retrieved from https://ageconsearch.umn.edu/record/16080/files/ep030099.pdf

10. Fatas, A., \& Mihov, I. (1999). Government Size and Automatic Stabilizers: International and Intranational Evidence (26 p.). In Conference Paper for Lessons from Intranational Economics for International Economics. Retrieved from http://faculty.haas.berkeley.edu/ arose/FM599.pdf

11. Fischer, S. (1992). Macroeconomic stability and growth. Cuadernos de Economía, 29(87), 171-186. Retrieved from https://www.jstor.org/ stable/23830518

12. Gali, J. (1994). Government size and macroeconomic stability. European Economic Review, 38(1), 117-132. https://doi.org/10.1016/00142921(94)90009-4

13. Granger, C. (1988). Some recent development in a concept of causality. Journal of econometrics, 39(1-2), 199-211. https://doi. org/10.1016/0304-4076(88)90045-0

14. Gupta, S., Clements, B., Baldacci, E., \& Mulas-Granados, C. (2005). Fiscal policy, expenditure composition, and growth in low-income countries. Journal of International Money and Finance, 24(3), 441-463. https://doi.org/10.1016/j.jimonfin.2005.01.004

15. Haroon, R., \& Jehan, Z. (2020). Measuring the impact of violence on macroeconomic instability: evidence from developing countries. Portuguese Economic Journal, 1-28. https://doi.org/10.1007/s10258-020-00188-y

16. Ismail, M., \& Hussain, F. (2012). Fiscal Discretion and Its Impact on Pakistan Economy. The Pakistan Development Review, 51(4), 339-362. Retrieved from https://www.jstor.org/stable/23734765

17. Keynes, J. (1936). The General Theory of Employment Interest and Money (472 p.). Macmilian Cambridge University Press.

18. Kumhof, M., \& Laxton, D. (2013). Simple fiscal policy rules for small open economies. Journal of International Economics, 91(1), 113-127. Retrieved from https://econpapers.repec.org/article/eeeinecon/v_3a91_3ay_3a2013_3ai_3a1_3ap_3a113-127.htm

19. Li, C. (2010). Government Size and Macroeconomic Stability: Sub-National Evidence from China (MPRA Paper No. 28226) (33 p.). Retrieved from https://mpra.ub.uni-muenchen.de/28226/1/MPRA_paper_28226.pdf

20. Miron, J. (2010). The Negative Consequences of Government Expenditure (Mercatus Centre Discussion Paper No. 10-55) (26 p.). Retrieved from https://www.mercatus.org/system/files/Miron_Research_Summary.pdf

21. Mohanty, M., \& Zampolli, F. (2009). Government Size and Macroeconomic Stability. BIS Quarterly Review, 55-68. Retrieved from https:// www.bis.org/publ/qtrpdf/r_qt0912.pdf

22. Musgrave, R. (1969). Fiscal Systems. New Haven: Yale University Press.

23. Okoro, A. S. (2013). Government spending and economic growth in Nigeria (1980-2011). Global Journal of Management and Business Research Economics and Commerce, 13(5), 21-29. Retrieved from https://globaljournals.org/GJMBR_Volume13/4-Government-Spendingand-Economic.pdf

24. ZimFact (2018). Zimbabwe's national debt: where does it stand? (p. 56). Retrieved from https://zimfact.org/zimbabwes-national-debtwhere-does-it-stand

25. Risquete, A., \& Ramajo, J. (2015). The Effect of Fiscal Policy on Spanish Economy:Keynesian or Non-Keynesian Behavior. Journal of Policy Modeling, 37(6), 1019-1048. https://doi.org/10.1016/j.jpolmod.2015.08.006

26. Saville, S. (2008). Government Spending and Inflation. Retrieved from http://www.safehaven.com/author/16/steve-saville

27. UNCTAD (2016). Global macroeconomic stability (pp. 178-179). In Development and globalization facts and figures. United Nations UNCTAD. Retrieved from https://stats.unctad.org/Dgff2016/DGFF2016.pdf

28. UNCTAD (2012). World investment report 2012: towards a new generation of investment policies (United Nations Conference on Trade and Development) (239 p.). New York: United Nations. Retrieved from https://unctad.org/system/files/official-document/wir2012 embargoed_en.pdf

29. Wagner, A. (1883). Three extracts on public finance (reprinted), In R. Musgrave \& A. Peacock (Eds.) (1958), Classics in the theory of public finance. London: Macmillan.

30. World Bank (2017). Zimbabwe Economic Update: The State in the Economy. Retrieved from https://www.worldbank.org/en/country/ zimbabwe/publication/zimbabwe-economic-update-the-state-in-the-economy 


\section{APPENDIX A}

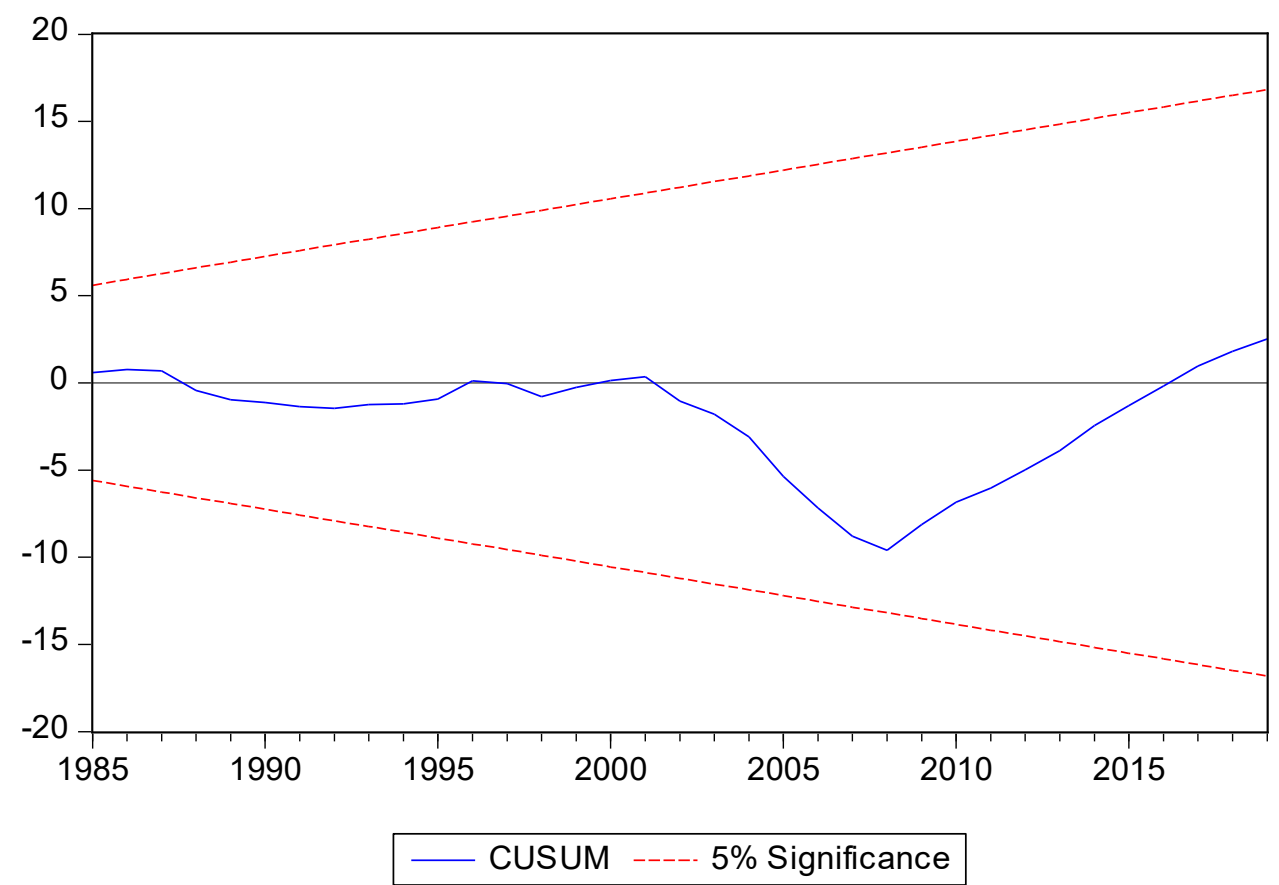

Source: Own computation

Figure A1. Diagnostic tests - Parameter stability DOLS

Inverse Roots of AR Characteristic Polynomial

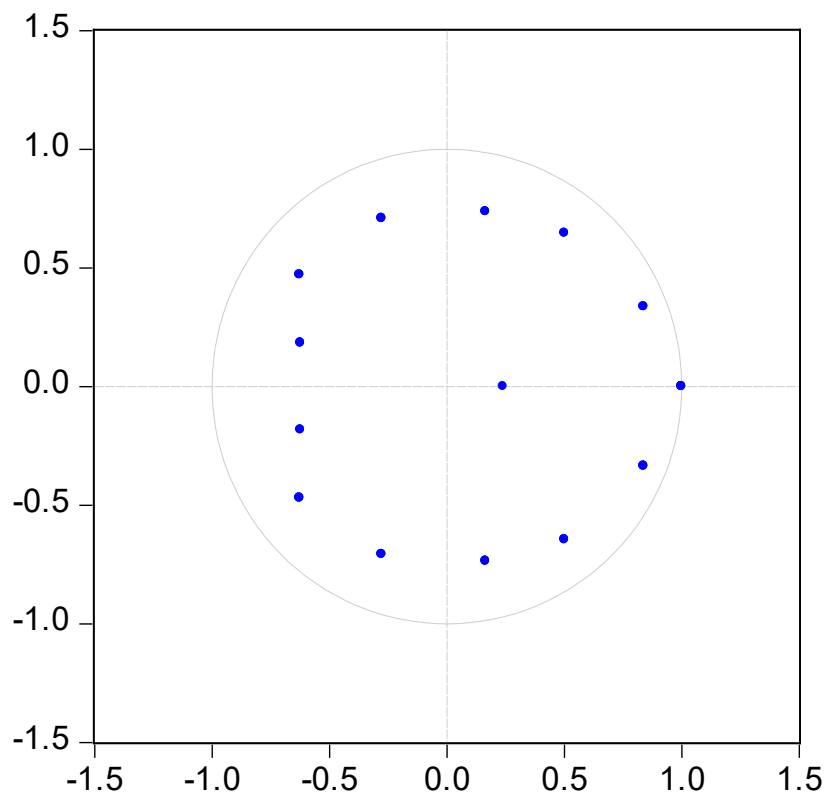

Figure A2. Dynamic stability- VECM 
Table A1. VECM Residual Normality

Source: Own computation.

VEC Residual Normality Tests

Orthogonalization: Cholesky (Lutkepohl)
Null Hypothesis: residuals are multivariate normal
Sample: 1981 2019
Included observations: 34

